\title{
In vitro safety assessment of papain on human skin: A qualitative Light and Transmission Electron Microscopy (TEM) study
}

\author{
Patrícia Santos Lopes ${ }^{1}$, Gabriele Wander Ruas ${ }^{2}$, André Rolim Baby ${ }^{1, *}$, Claudinéia Aparecida Sales \\ de Oliveira Pinto', li-sei Watanabe ${ }^{3}$, Maria Valéria Robles Velasco', Telma Mary Kaneko
}

${ }^{1}$ Department of Pharmacy, School of Pharmaceutical Sciences, University of São Paulo, ${ }^{2}$ Faculty of Pharmaceutical Sciences Oswaldo Cruz, ${ }^{3}$ Institute of Biomedical Sciences, University of São Paulo

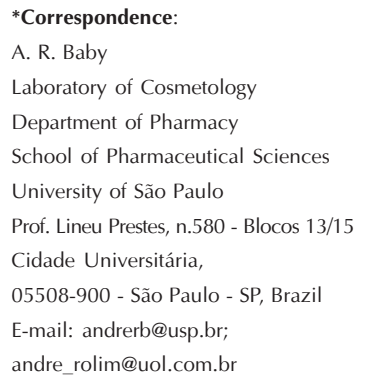

Papain is a thiol proteolytic enzyme widely used in dermatology that found applications in wound treatment. Recently, papain was also used as absorption enhancer which can modify the peptidel protein material in the bilayer domain. We investigated papain safety using human skin that was exposed to papain in vitro at different times: 4, 24 and 48 hours. The samples were examined using Light and Transmission Electron Microscopy (TEM) to study of the mechanisms involved in enhancer-skin interaction. After 24 hours, changes occurred in corneosomes. However, samples of 48 hours did not show major changes in agreement with the control. These findings indicated that papain could be used safely onto the skin.
Uniterms

- Transmission electron microscopy/ qualitative analysis

- Light microscopy/ qualitative analysis

- Stratum corneum

- Papain/ cosmetic use

- Human skin/ cosmetology

\section{INTRODUCTION}

Human skin, and specifically the stratum corneum, as an effective and selective barrier, provides the major control to chemical permeation (Barry, 2001; Elias, 2005; Baby et al., 2006). The penetration process presents three potential pathways to the viable tissue - through hair follicles with associated sebaceous glands, via sweat ducts or across continuous stratum corneum. The last one is the choice of most of the compounds, which can bypass through the corneocytes (transcellular microroute) or through regions of the semicrystalline gel composed of multiple liquid bilayers of ceramides, fatty acids, cholesterol and cholesterol esters (intercellular microroute) (Barry, 2001). The stratum corneum is regarded as a heterogeneous twocompartment system composed of keratin-filled corneocytes, embedded in a lipid-enriched intercellular matrix. The lipid lamellae are formed by rearrangement of lamellar disks that are extruded from the uppermost cells of the stratum granulosum (Bergh et al., 1999).

Enzymes can interfere on the percutaneous absorption of drugs by two ways: like a penetration enhancer or producing a delayed absorption. Papain is a thiol proteolytic enzyme widely used in dermatology that has found application in wound treatment. Recently, papain was also used as absorption enhancer which can modify the peptide/ protein material in the bilayer domain (Fein et al., 2005; Pinto et al., 2007).

The stratum corneum contains several proteases that may play a central role in the desquamation process. The first enzyme discovered was Stratum Corneum Chymotryptic Enzyme (SCCE ) followed by Stratum Corneum Tryptic Enzyme (SCTE). Both of them may be involved in this complex process (Marzulli, Maibach, 1996; Caubet et al., 2004; Brattsand et al., 2005). Bernard and co-workers (2003) have described a thiol protease, probably expressed 
as a pro-enzyme, in the lower layers of the epidermis and in part activated by an unidentified mechanism in the upper layers during differentiation of the keratinocytes. Therefore, papain, a thiol protease, could be a safe penetration enhancer candidate (Bernard et al., 2003).

The aim of this research work was to study the possible behavior by which papain could act as a safe penetration enhancer using Light and Transmission Electron Microscopy (TEM).

\section{MATERIAL AND METHODS}

Human skin, obtained from breast plastic surgery, was cleaned and cut in small pieces measuring $2 \mathrm{~cm}^{2}$ and placed in $60 \mathrm{~mm}$ culture dishes, processed the same day of the surgery. Subcutaneous fat was removed and the skin cleaned with saline solution. A solution of $0.2 \%(\mathrm{w} / \mathrm{v})$ papain $+0.04 \%(\mathrm{w} / \mathrm{v})$ cystein in KGM (keratinocytes growth medium) was applied to the stratum corneum (1.96 $\mathrm{cm}^{2}$-steel rings) for different periods of contact: 4, 24 and $48 \mathrm{~h}$. A control was run at the same conditions, without papain and cystein.

Skin samples were removed immediately following the application period and were fixed in $5 \mathrm{~mL}$ of Karnovsky's fixative solution overnight at $25^{\circ} \mathrm{C}$. Samples were washed in phosphate-buffered saline (PBS) pH 7.4 for three times and post-fixed in $2 \%$ osmium tetroxide for $2 \mathrm{~h}$ at $4{ }^{\circ} \mathrm{C}$. A third fixative was used, $0.5 \%$ uranyl acetate, for $36 \mathrm{~h}$. Following fixation, the specimens were washed and dehydrated in a range of ethanol solutions $(70,80,90,95$, $100 \%$ ), changed in propylene oxide and embedded in 1 part of propylene oxide and 1 part of Spurr's resin. During infiltration, the vials of tissue were gently shaken on a turntable that positioned the vials at about $30^{\circ}$ from the vertical, and slowly rotated the tissue. This mixture was left overnight and changed for Spurr's resin for $4 \mathrm{~h}$, changed again and left for $1 \mathrm{~h}$ more at $37^{\circ} \mathrm{C}$. The final step in embedding was curing the tissues blocks by polimerization of the epoxy mixture. The resin was placed in polyethylene capsules, and the tissue cube was placed into the resin to gradually sink in the bottom for 5 days at $60 \mathrm{C}$. Thin sections were done with ultramicrotome (Leica Ultracut ${ }^{\text {B }}$ UCT), using glass lamina followed by fixing with chloroform which was evaporated in hot plate. Then, the sections were stain with toluidine blue and they were observed and photographed in the light microscope to determine which ultrathin sections should be done. Ultrathin sections $(60 \mathrm{~nm})$, obtained with diamond lamina, were stained with $4 \%$ uranyl acetate alcoholic solution for 30-40 min and washed with ethanol, water, and next with $0.4 \%$ lead citrate for $3 \mathrm{~min}$. Grids of $200 \mathrm{mesh}$ were examined in a JEOL 1010 transmission electron microscope and photographed with Kodak Electron Microscope - Estar thick base 4489, 100, $8.3 \times 10.2 \mathrm{~cm}$ and stored in the laboratory computer. The protocols for the sample preparations were the same used in the Anatomy Department of Biomedical Institute of Sciences - ICB III.

The experiments have been carried out under approval of Ethic Committee of Department of Pharmacy at University of São Paulo, Brazil (CEP/ FCF/USP n ${ }^{\circ} 229$ ).

\section{RESULTS AND DISCUSSION}

According to the results, corneosomes (or corneodesmosomes) were affected by papain when compared to control. Figure 1 illustrates the untreated epidermis (control). Corneosomes in untreated epidermis was characterized by an extracellular electron dense plug, which merged imperceptibly with the outer lipid envelope leaflets of corneocytes (Figure 1B).

Corneodesmosomes are intercellular junctions of the tissue from the molecular modification of desmosomes and persist in the stratum corneum up to its surface (Haftek et al., 1999). The desmosome or macula adherens forms plaque-like structures that, in thin sections, have an appearance similar to the zonula adherens, but the desmosome contains a definite intermediate dense line that lines within the intercellular space and parallels the cell surface (Bozzola, Russel, 1992).

The stratum corneum proteins are extensive crosslinked with both cell envelope and intracellular proteins. Therefore, increased diffusion across the corneocytes should have resulted from alterations in its structure. A decrease in crosslinking density at the cell envelope would allow diffusivity enhancement through cell (Suhonen et al., 1999).

Proteolytic digestion, after $24 \mathrm{~h}$ papain $0.2 \%(\mathrm{w} / \mathrm{v})$ contact, induced dramatic changes (Figure 2). A large amount of the intercellular material was lost in the first layer of stratum corneum. Corneosomes, identified by rudiments of their attachment plaques, were devoid of their plug material, most of the extracellular components were digested and corneocytes were separated (Figure 2B). Details of corneodesmosomes released are showed in Figure 3, where it can be seen the amount of tonofilaments, intermediate filaments usually composed of keratin, that make hairpins turns at the junctional density (Bozzola, Russel, 1992).

The ultra structural appearance of corneodesmosomes suggested that they were modified during the transition between viable epidermis and cornified epidermal layers. Part of this change may be explained to the incorporation of 


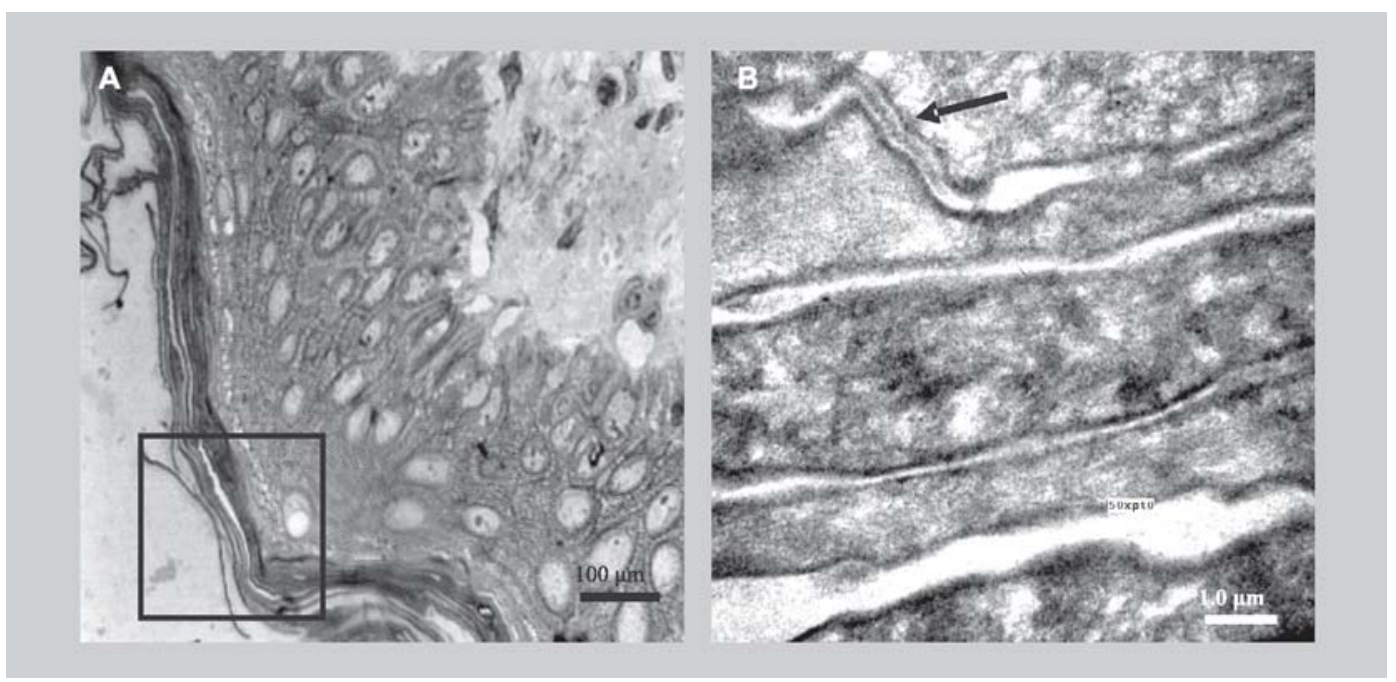

FIGURE 1 - (A) Light microscope micrograph of human epidermis. (B) Transmission electron micrograph of control, untreated epidermis. The corneosomes are characterized by an extracellular electron dense plug (black arrow).

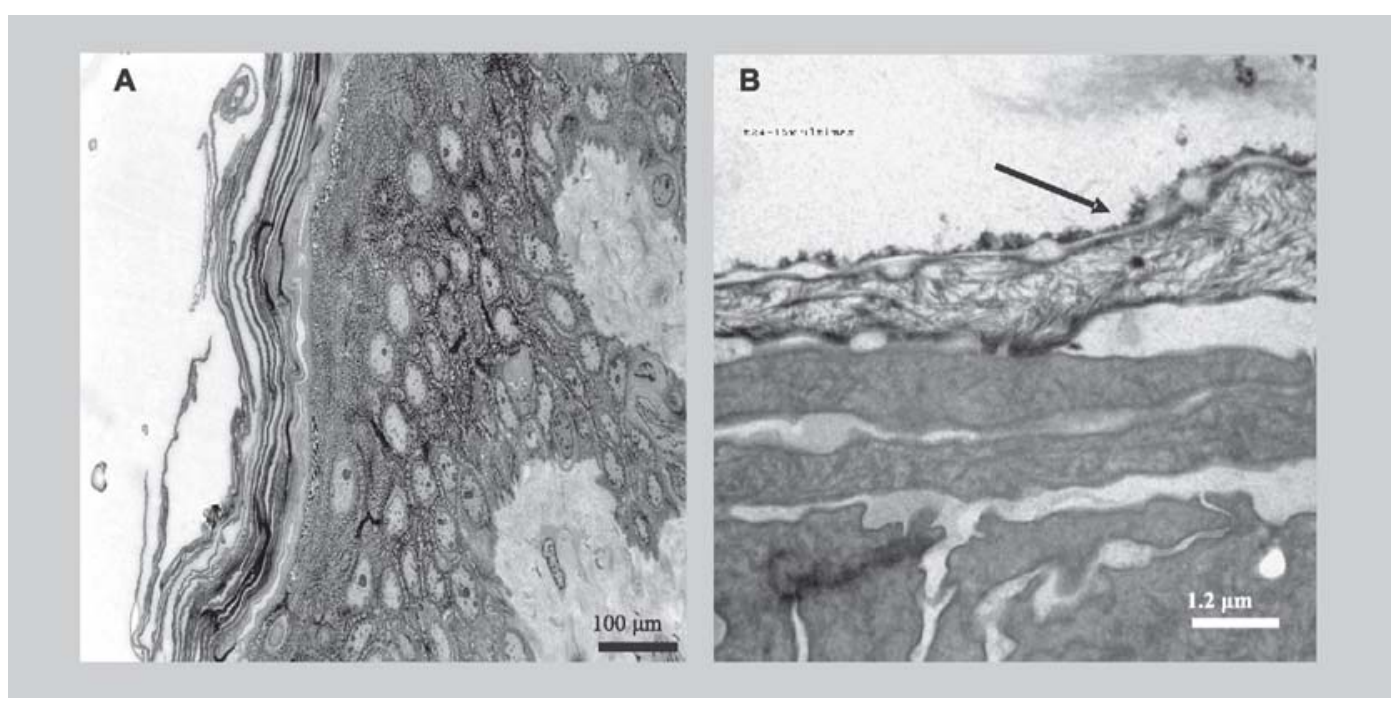

FIGURE 2 - (A) Light microscope micrograph of human epidermis after $24 \mathrm{~h}$ papain treatment. (B) Transmission electron micrograph of $24 \mathrm{~h}$ enzymatic treatment disrupts the corneosome bond (arrow) and modified the superficial stratum corneum layer.

proteins. One of this is corneodesmosin, a $52-\mathrm{kD}$ protein that is specifically expressed in cornified epidermal layer. It is found intracellularly in association with lamellar bodies, in the stratum granulosum and in the transition zone between the stratum granulosum and the stratum corneum, coinciding with the change in ultrastructural appearance of the desmosomes, when corneodesmosin is translocated to the extracellular parts of desmosomes and is continuously degraded to smaller constituents of the stratum corneum (Marzulli, Maibach, 1996).

After $48 \mathrm{~h}$, the contents of outer edges corneocytes were leached, but the cell adhesion was still maintained by corneosomes (Figure 4A). The first layer remained unscathed although the next ones showed lower contact (Figure 4B). TEM micrographs of epithelia treatment during $48 \mathrm{~h}$ (Figure 4B), showed that the upper layer of the stratum corneum had no changes, while those on keratin cytoesqueletal appeared only in the second layer. As well, it was possible to see the corneodesmosomes maintenance.

The stratum corneum recovery happened after $48 \mathrm{~h}$ of treatment, as is shown in Figure 5, where it is possible to note the existence of a major number of cells in each layer. 


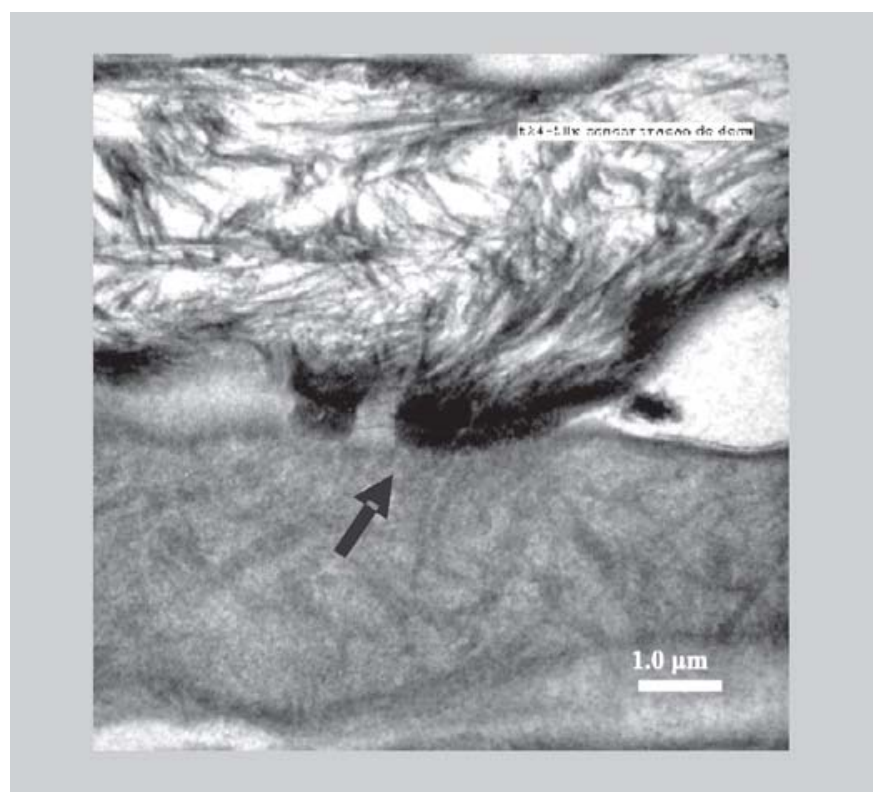

FIGURE 3 - Transmission electron micrograph of human skin after treatment during 24 hours using papain $0.2 \%(\mathrm{p} /$ v). Arrow indicates an amount of tonofilaments.

The cause of these in vitro changes is unknown, but they may reflect activation of endogenous mechanisms that could neutralize or recover the corneocytes adhesion. These results were substantiated with cell culture and corroborated data from biophysics techniques, like differential scanning calorimetry (DSC), attenuated total reflectance Fourier transform infrared spectroscopy (ATR-FTIR), photoacustic spectroscopy (PAS) and Fourier transform Raman spectroscopy (FT-Raman) (data not showed).

The desquamation process is controlled by specifics enzymes, which hydrolyzed corneodesmosomes releasing the dead cells in skin surface. It is precisely controlled by a cascade of events, a molecular mechanism that is not completely known (Bernard et al., 2003). It has been shown that these specific enzymes are produced in keratinocytes. The thiol group present in the active site of these enzymes is responsible for cleaving the peptide bond, more efficiently than triglycolic acid and cystein (Egelrud, 2000). Papain, as a thiol proteolytic enzyme, could be acting in the same way that these enzymes.

According to the results, TEM micrographs of epithelia after treatment during $24 \mathrm{~h}$ using papain, showed changes in the stratum corneum cohesion, this structures lost integrity (Figure 3). On the other hand, treatment during $48 \mathrm{~h}$ showed no changes in the upper layer of the stratum corneum (Figure 4).

\section{CONCLUSION}

Papain $0.2 \%(\mathrm{w} / \mathrm{v})$ promoted a proteolytic digestion of stratum corneum first layers and induced a decreased crosslinking in corneosomes region. In the treated samples, after $48 \mathrm{~h}$, the stratum corneum was recovered. These results suggested that papain could be used safely used due to reversibility of barrier function of stratum corneum.

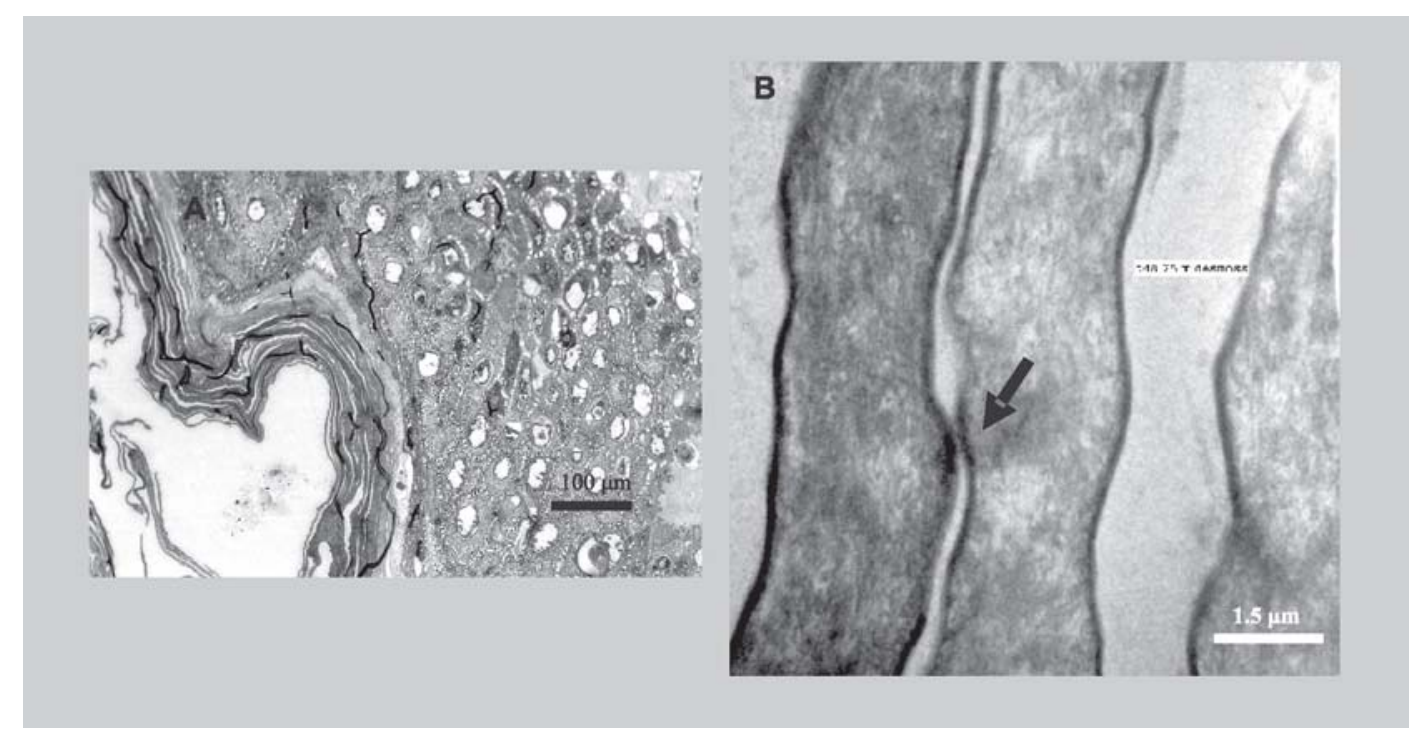

FIGURE 4 - (A) Light microscope micrograph of human epidermis after 48h papain treatment. (B) Transmission electron micrograph of stratum corneum first layers after 48 hours. Corneosomes bonds (black arrow) appeared recovered. 


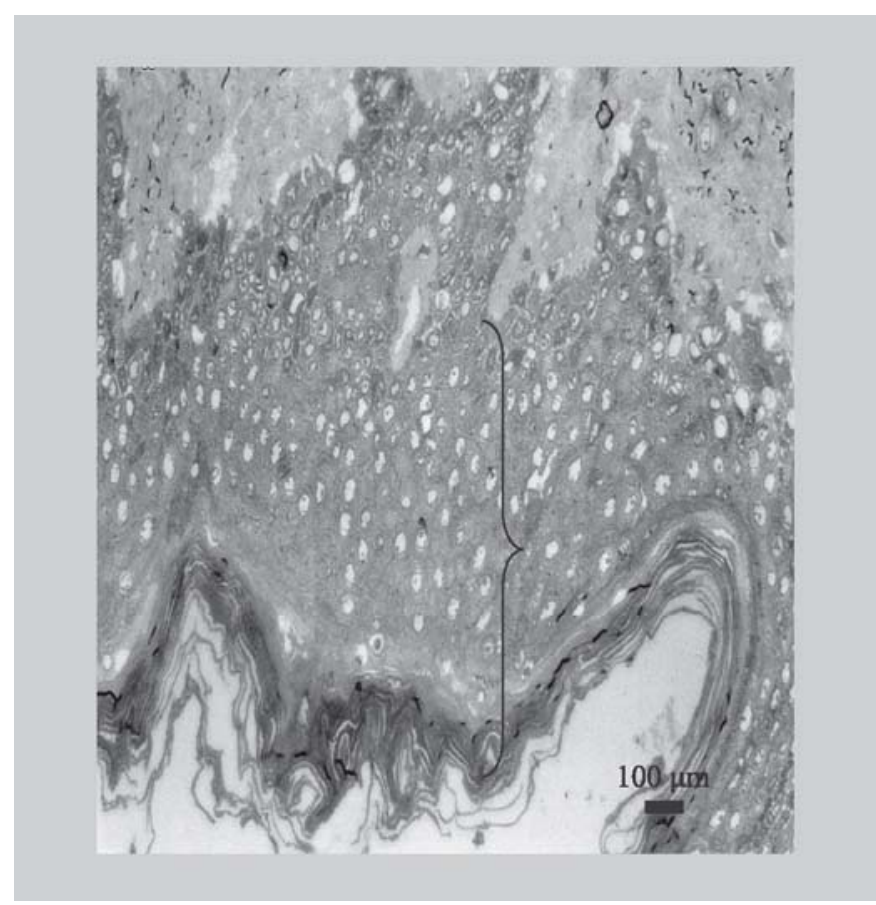

FIGURE 5 - Light microscope micrograph of human skin after treatment for 48 hours using papain $0.2 \%(\mathrm{p} / \mathrm{v})$.

\section{ACKNOWLEDGEMENTS}

We are grateful to Dr. Monica Mathor, Dr. Marisa Roma Herson and the Reviewers of this research work for their suggestions, contributions and kindly help. This work was supported by National Council for Scientific and Technological Development (CNPq), foundation linked to the Ministry of Science and Technology (MCT), to support Brazilian research and CAPES.

\section{RESUMO}

\section{Avaliação in vitro da segurança de uso da papaína em pele humana: Estudo qualitativo por microscopia de luz e eletrônica de transmissão (MET)}

Papaína é uma enzima proteolítica amplamente utilizada na dermatologia para o tratamento de feridas. Atualmente, a papaína também tem sido empregada como promotor de absorção cutânea passivel de modificar os dominios protéicos da epiderme. Nesta pesquisa investigou-se in vitro a segurança da papaína, utilizando pele humana exposta a enzima em diferentes períodos de tempo de contato: 4, 24 e 48 horas. As amostras foram avaliadas por Microscopia de Luz e Eletrônica de Transmissão (MET), técnicas que podem ser utilizadas no estudo dos mecanismos envolvidos na interação de promotores de absorção cutânea e a pele. Após 24 horas de contato entre a pele a solução de papaina, mudanças ocorreram nos corneossomos, no entanto, as amostras em contato por 24 horas não evidenciaram alterações relevantes comparadas com o controle. Os resultados indicaram que a papaina poderia ser seguramente aplicada sobre a pele.

UNITERMOS: Microscopia eletrônica de transmissão/ análise qualitativa. Microscopia óptica/análise qualitativa. Extrato córneo. Papaína/ uso cosmético. Pele humana/cosmetologia.

\section{REFERENCES}

BABY, A.R.; LACERDA, A.C.L.; VELASCO, M.V.R.; LOPES, P.S.; KAWANO, Y.; KANEKO, T.M. Evaluation of interaction of sufactants with stratum corneum model membrane from Bothrops jararaca by DSC. Int. J. Pharm., Amsterdam, v. 317, n. 1, p. 7-9, 2006.

BARRY, B.W. Novel mechanisms and devices to enable successful transdermal drug delivery. Eur. J. Pharm. Sci., Amsterdam, v. 14, n. 2, p. 101-114, 2001.

BERGH, B.A.; VROOM, J.; GERRITSEN, H.; JUNGINGER, H.E.; BOUWSTRA, J.A. Interactions of elastic and rigid vesicles with human skin in vitro: electron microscopy and two-photon excitation microscopy. Biochim. Biophys. Acta, Amsterdam, v. 1461, n. 1, p. 155173, 1999.

BERNARD, D.; MÉHUL, B.; THOMAS-COLLIGNON, A.; SIMONETTI, L.; REMY, V.; BERNARD, M.A.; SCHMIDT, R. An alysis of proteins with caseinolytic activity in a human stratum corneum extract revealed a yet unidentified cysteine protease and identified the so-called "stratum corneum thiol protease" as cathepsin L2. J. Invest. Dermatol., Baltimore, v. 120, n. 4, p. 592-600, 2003.

BOZZOLA, J.J.; RUSSELL, L.D. Electron microscopy: principles and techniques for biologists. Boston: Jones and Bartlett Publishers, 1992. 542p.

BRATTSAND, M.; STEFANSSON, K.; LUNDH, C.; HAASUM, Y.; EGELRUD, T. A proteolytic cascade of kallikreins in the stratum corneum. J. Invest. Dermatol., Baltimore, v. 124, n. 1, p. 198-203, 2005.

CAUBET, C.; JONCA, N.; BRATTSAND, M., GUERRIN, 
M.; BERNARD, D.; SCHMIDT, R.; EGELRUD, T.; SIMON, M.; SERRE, G. Degradation of corneodesmosome proteins by two serine proteases of the kallikrein family, SCTE/KLK5/hK5 and SCCE/KLK7/ Hk7. J. Invest. Dermatol., Baltimore, v. 122, n. 5, p. 12351244, 2004.

EGELRUD, T. Desquamation in the stratum corneum. Acta Derm.-Venereol., Stockholm, v. 80, supl. 208, p. 44-45, 2000.

ELIAS, P.M. Stratum corneum defensive functions: An Integrated View. J. Invest. Dermatol., Baltimore, v. 125, n. 2, p.183-200, 2005.

FEIN, H.; MAYTIN, E.V.; MUTASIM, D.F.; BAILIN; P.L. Topical protease therapy as a novel method of epidermal ablation: Preliminary report. Dermatol. Surg., New York, v. 31, n. 2, p. 139-148, 2005.
HAFTEK, M.; TEILLON, M.H.; SCHMITT, D. Stratum corneum, corneodesmosomes and ex vivo percutaneous penetration. Microsc. Res. Tech., New York, v. 43, n. 3, p. 242-249,1999.

MARZULLI, F.N.; MAIBACH, H.I., (Eds.). Dermatotoxicology. Washington: Taylor \& Francis, 1996. $713 p$.

PINTO, C.A.S.O.; GREEN, D.; BABY, A.R.; RUAS, G.W.; KANEKO, T.M.; MARANA, S.R.; VELASCO M.V.R. Determination of papain activity in topical dosage forms: single laboratory validation assay. Lat. Am. J. Pharm., Buenos Aires, v. 26, n. 5, p. 771-775, 2007.

SUHONEN, T.M.; BOUWSTRA, J.A.; URTTI, A. Chemical enhancement of percutaneous absorption in relation to stratum corneum structural alterations. J. Control. Release, Amsterdam, v. 59, n. 2, p. 149-161, 1999.

Recebido para publicação em 06 de julho de 2007. Aceito para publicação em 23 de novembro de 2007. 